\title{
A state of the art review on reinforced concrete beams with openings retrofitted with FRP
}

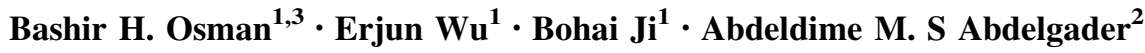

Received: 21 September 2015/ Accepted: 29 July 2016/Published online: 15 August 2016

(c) The Author(s) 2016. This article is published with open access at Springerlink.com

\begin{abstract}
The use of externally bonded fiber reinforced polymer (FRP) sheets, strips or steel plates is a modern and convenient way for strengthening of reinforced concrete (RC) beams. Several researches have been carried out on reinforced concrete beams with web openings that strengthened using fiber reinforced polymer composite. Majority of researches focused on shear strengthening compared with flexural strengthening, while others studied the effect of openings on shear and flexural separately with various loading. This paper investigates the impact of more than sixty articles on opening reinforced concrete beams with and without strengthening by fiber reinforcement polymers FRP. Moreover, important practical issues, which are contributed in shear strengthening of beams with different strengthening techniques, such as steel plate and FRP laminate, and detailed with various design approaches are discussed. Furthermore, a simple technique of applying fiber reinforced polymer contributed with steel plate for
\end{abstract}

Bashir H. Osman

bashir00@yahoo.com

$\triangle$ Erjun $\mathrm{Wu}$

wwwerjun@hotmail.com

Bohai Ji

hhbhji@163.com

Abdeldime M. S Abdelgader

abdeldime@hotmail.com

1 Civil Engineering Department, College of Civil and Transportation Engineering, Hohai University, No. 1 Xikang Rd., Nanjing 210098, Jiangsu, China

2 College of Engineering, Karary University, Khartoum 12304, Sudan

3 Civil Engineering Department, Engineering College, Sinnar University, Sinnar, Sudan strengthening the RC beams with openings under different load application is concluded. Directions for future research based on the existing gaps of the present works are presented.

Keywords Web opening - Carbon fiber reinforced polymer $\cdot$ RC beams $\cdot$ Shear strengthening $\cdot$ FRP

\section{Introduction}

Transverse opening in reinforced concrete beams is a facility that allows the utility line to pass through the structure. This type of design encourages the designer to reduce the height of the structure consequently leads to an economical design. Due to the sudden changes in the cross section of the beam, the edges of the opening can be subjected to stress concentration, and it is possible to induce transverse cracks in the beam (Fig. 1). Particularly in rehabilitation works and newly builds structure, the external bonding of high-strength fiber reinforced plastics (FRP) has widely gained popularity in recent years to strength the structural concrete members. Comprehensive experimental investigations has been conducted to show that the strengthening method has several advantages over the traditional ones, especially due to its corrosion resistance, high stiffness-to-weight ratio, improved durability and flexibility in its usage over steel plates. The maintenance, rehabilitation and upgrading of structural members perhaps are the most crucial problems in civil engineering applications. Difference in members design using absolute design codes in different parts of the world is structurally unsafe compared to the new design codes. Since replacement of such deficient elements of structures incurs a huge amount of public amount and time, strengthening has 
Fig. 1 Typical shear failure of a beam with small openings

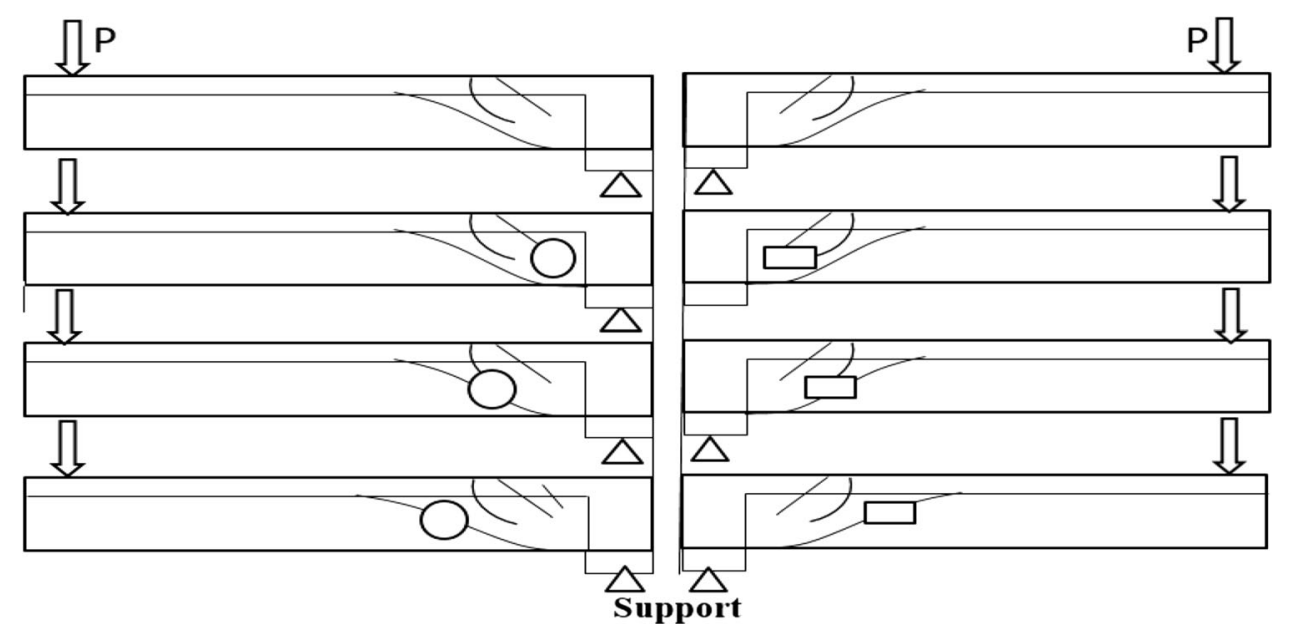

become the acceptable way of improving their load carrying capacity and extending their service lives (Alferjani et al. 2013). The use of FRP materials in civil infrastructure for the repair and strengthening of reinforced concrete structures and for new construction has become a common practice. The most efficient technique for improving the shear strength of deteriorated RC members is to externally bond FRP plates or sheets (Kim et al. 2008). When the FRP was compared with steel materials, it was found that it provided unique opportunities to develop the shapes and forms, to facilitate their use in construction. Although, the materials used in FRP such as, fiber and resins are relatively expensive when compared with traditional materials, considering that the FRP equipment installation systems are lower in cost (Alferjani et al. 2013).

\section{The usage of FRP in engineering practice}

FRP usage in civil engineering works dates back to the 1950s when glass fiber-reinforced polymer (GFRP) bars were first investigated for structural use. It was finally considered for structural engineering applications, owing to its superior performance when joint with epoxycoated steel. Due to its poor performance within thermosetting resins cured at high molding pressures, GFRP was not succeed in the first applications (Reinforcing Concrete Structures with Fibre Reinforced Polymers 2007).

FRP in civil engineering can be classified into: for new constructions repair and rehabilitation applications, and architectural applications (Fig. 2). It widely emerged in the structures design such as, bridges and columns built completely out of FRP composites. It also demonstrated exceptional durability and effective resistance to the effects of environmental exposure. Figure 3 show the configuration of FRP application.

\section{Previous studies on RC beams with openings}

\section{Experimental studies of opening beams without strengthening}

Ultimate strength RC beam that contained a large rectangular opening and subjected to a point load was investigated by Mansur et al. (1984). The proposed method used in their study showed that the distribution of external shear between the chord members and the collapse load of the beam mainly depend on the cross-sectional properties, size and location of the opening. Their theoretical results showed good agreement with experimental results. Torunbalci (2000) utilized the nonlinear finite element method to study the behavior of reinforced concrete beams containing small square openings under increasing loads. The effects of section reduction due to the openings on the load-carrying capacity of the beams and the important design parameters, such as opening locations and presence of web reinforcement are investigated. Torunbalci (2002) experimentally investigated the behavior of $\mathrm{RC}$ beams with large rectangular opening to study the effects of opening locations and the presence of web reinforcement on shear strength. The results showed that the distribution of external shear between the chord members and the collapse load of the beam depends not only on the cross-sectional properties, but also on the size and location of the opening.

The effects of introducing a transverse opening on the behavior and strength of reinforced concrete beams under shear are presented and discussed in Mansur (1998). To classify the opening as large or small, some guidelines were observed. There are two types of diagonal tension failure that have been identified for small openings. A simplified method of design using the current codes of practice and numerical examples was proposed. Ashour and Rishi (2000) examined the continuous RC deep beams 


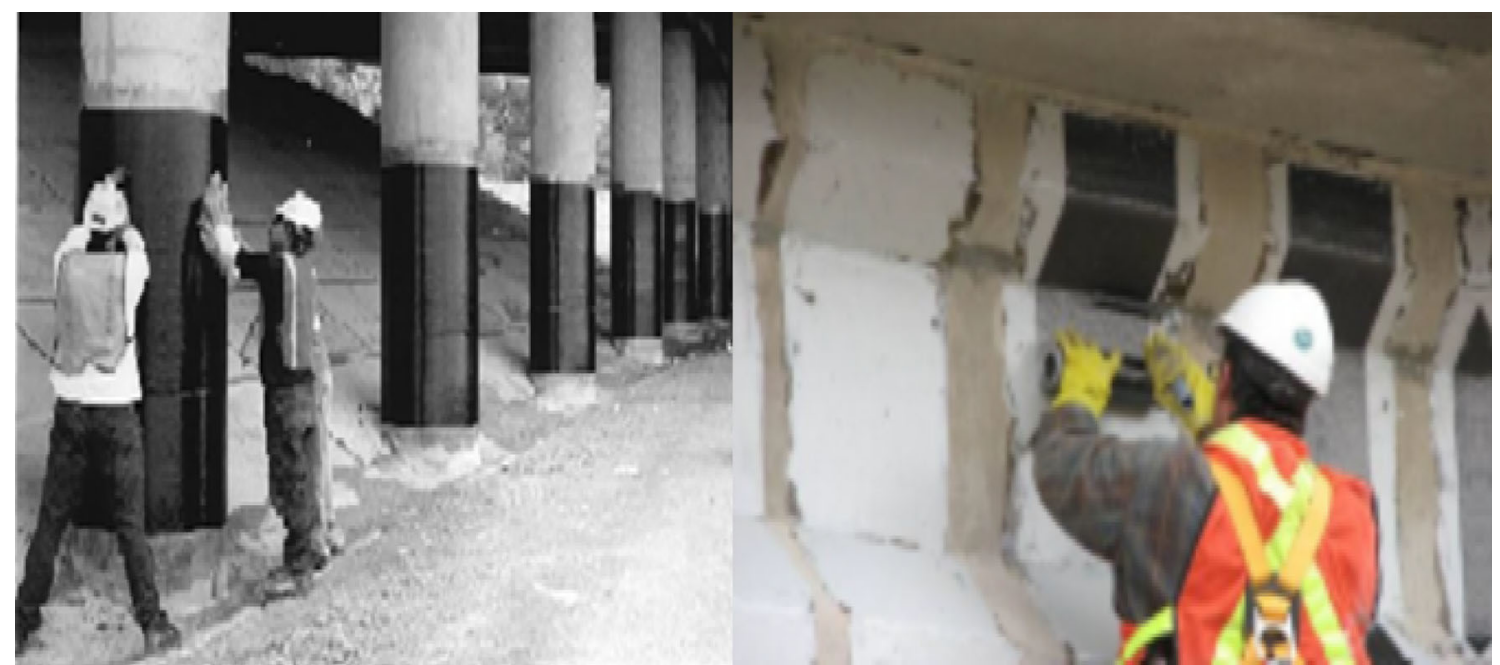

Fig. 2 Practicing strengthening of RC girder by CFRP laminate (Alferjani et al. 2014)

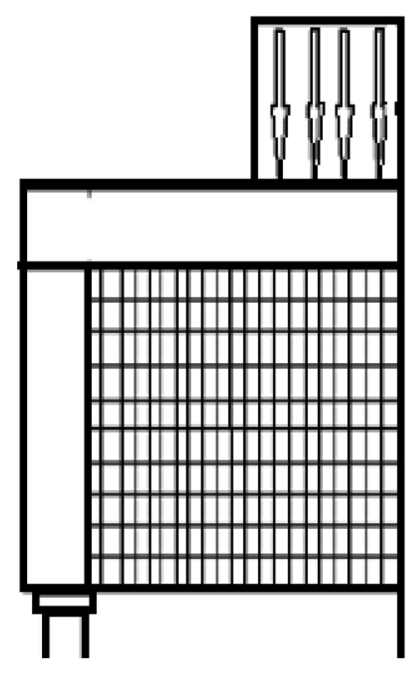

(1) $0^{0} / 90^{0}$

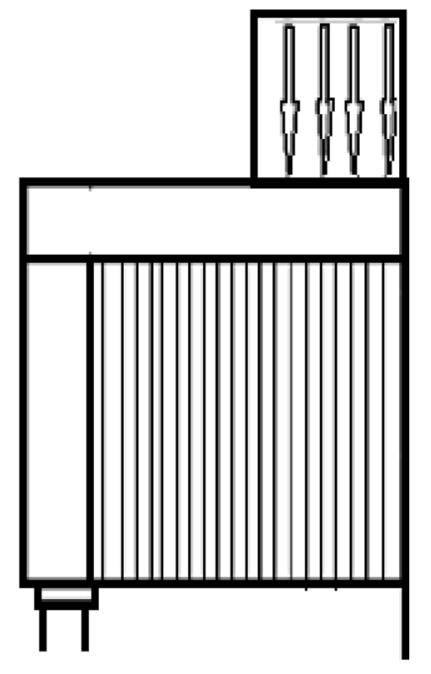

(2) $90^{\circ}$

Fig. 3 FRP configuration

with small and large rectangular web openings. Experiments indicated that the reduction in the load capacity due to the provision of openings decreases as the openings are located closer to the end supports. High-strength RC deep beams with rectangular cross section were tested by Yang et al. (2006). results showed that concrete strength has a lesser influence on the shear strength of deep beams with openings compared to solid beams and this effect increases as the shear span-to-depth $\left(\frac{a_{\mathrm{v}}}{d}\right)$ ratio decreases. Diagonal cracks connecting the four corners of the opening to the loading and support points were found to cause the final shear failure. An experimental investigation on the strength and behavior of reinforced concrete beams with shear openings was carried out to evaluate the efficiency of using CFRP sheets for control local cracks around openings and

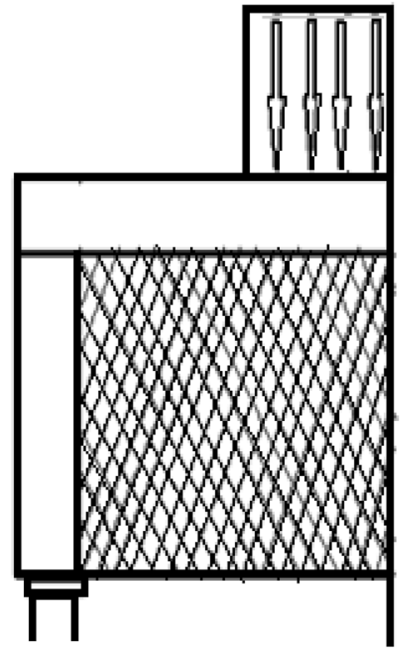

(3) $\pm 45^{0}$

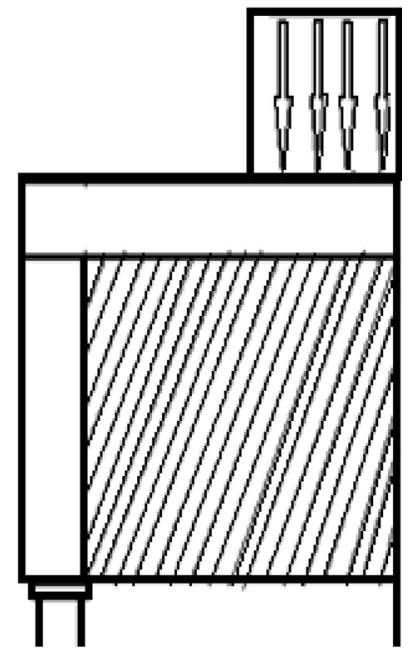

(4) $45^{0}$ to resist excessive shear stresses in the opening regions (Abdalla et al. 2003). The effect of strengthening technique on several design parameters such as amount and configuration of the FRP sheets around the opening, deflection, strain, opening width and depth, ultimate load and cracking was investigated. The design of steel and composite beams with reinforced or unreinforced web openings using unified approach was presented by Darwin and Lucas (1990) and Darwin and Donahey (1988). The procedures included solutions for the pure moment and pure shear strengths at openings, as well as a direct solution for member capacity at openings that subject to both bending and shear. Resistance factors obtained for steel is 0.929 and composite beams is 0.876 . Based on their analysis, resistance factors of 0.90 and 0.85 used for steel and composite beams in a 
flexure appear to be good choices for both bending and shear at web openings.

The behavior and analysis of thirteen RC concrete beams with square and circle openings strengthened by externally installed FRP rods were studied in which two types of strengthening are carried out by Pimanmas (2010). The first type is to place FRP enclosing the opening and the second one is to place FRP diagonally to the beam. When FRP rods are placed diagonally to the beam's axis alongside the opening throughout the entire beam's depth, the original performance is almost completely recovered. The finite element analysis demonstrated that placing FRP rods far away from the opening does not provide strengthening effect on the beam. Their analysis proved that inclined FRP rods are more effective than vertical ones. The results of 12 reinforced fiber concrete deep beams with rectangular openings in the web are reported in Mansur and Alwis (1984). The volume fraction of fibers, opening location, shear span to effective depth ratio and the amount of web reinforcement are considered as main parameters. The experimental results showed that the behavior and strength of deep beams was affected by the amount of web reinforcement (either in the form of discrete fibers or as continuous reinforcement) and the location of opening. An experimental investigation on eight reinforced-concrete continuous beams containing a large transverse opening is carried out in Mansur et al. (1991). Test results indicate four clear different stages of behavior in the load-deflection curve of a continuous beam. Failure of the beam occurs by the formation of plastic hinges at the opening regions. The results concluded that the increase in the length or depth of opening decreases the strength and stiffness of the beam and increases the crack width. Moreover larger deflections produced and early beam failure occurred when openings located in a high moment region. Analysis of 21 steelconcrete composite beams with rectangular web openings was carried out by Fahmy (1996). The effect of the opening eccentricity, opening height and opening length on the strength of the composite beam were presented. The results showed that the strength of beams is affected by opening height and length, and the decrease of positive openings eccentricity decreases the strength of the composite beam and vice versa. The experimental and analytical evaluation of $20 \mathrm{RC}$ deep beams with openings and low shear span-todepth ratio was studied. Results showed that the reduction in load-carrying capacity occurs if the opening is placed within the shear span about $18-30 \%$, but if the opening located in the mid-span, it does not influence the response of the beam. ATENA code was used to predict analytical model and compared with experimental results. The results from proposed approach are in a good agreement with the experimental values and finite element analysis (Campione and Minafò 2012).
Aykac et al. (2013) tested nine RC beams with a $150 \times 400 \mathrm{~mm}$ rectangular section and with a span length of $3900 \mathrm{~mm}$ to investigate the influence of multiple web openings along the length on strength parameters. Test parameters considered in their study are, the flexural reinforcement, the opening geometry, and the arrangement and material properties of the diagonal reinforcement around the openings. The experimental results indicated that the amount of tension reinforcement and reinforcement ratio had a great effect on beam behavior, test results were compared to that estimated from available equations. Structural idealization for deep beams with web openings was studied (Kong and Sharp 1977; Kong et al. 1978). The idealization was based on pilot tests on 24 beams, and checked against a further 32 tests covering a much wider range of web openings and web reinforcement patterns. An improved shear strength equation and design observations are presented in their study.

Aykac et al. (2014) studied RC beams with and without multiple web openings to investigate the effects of opening geometry, the use of longitudinal stirrups in the posts between the openings, the use of diagonal reinforcement around openings, and the longitudinal reinforcement ratio on the flexural behavior of $\mathrm{RC}$ beams with openings. The results showed that reinforced concrete beams with circular openings were found to have higher load capacities and ductility than beams with rectangular openings. Beams made by normal and high strength concrete were studied by Javad and Morteza (2004).They investigated the effect of small circular opening on the shear and flexural and ultimate strength. The opening diameter, the position of opening, the type and location of reinforcement around the opening and changes in the strength of concrete are the main factors of the investigation. The results showed that the presence of diagonal reinforcement and stirrups in top and bottom of opening is useful. Tan et al. (2001) examined the adequacy of the ACI Code approach modified for the inclusion of transverse openings and for shear design of a beam with circular openings. The test results indicated that crack control and preservation of ultimate strength may be achieved by providing reinforcement around the opening. Later the premature crushing of the concrete can be avoided by reduce the high stress in the compression chord by using diagonal bars. The behavior of steel reinforced concrete (SRC) beams with an opening including the effects of various opening shapes and different values of moment to shear ratio on the strength was investigated by Chen et al. (2008). The experimental study showed that the failure of the specimens with low moment to shear ratio by shear cracking and specimens with high moment to shear ratio demonstrated ductile 
behavior due to the confinement attributed to the stirrup and structural steel.

The effect of small circular opening on the shear and flexural and ultimate strength of beams was studied by Saksena and Patel (2013).The changes of diameter and openings positions are the main factors of their study. The results showed that the presence of diagonal reinforcement and stirrups in top and bottom of opening is more significant. Vengatachalapathy and Ilangovan (2010) studied experimentally the behavior and ultimate strength of steel fiber reinforced concrete (SFRC) deep beams with and without web openings subjected to two-point loading. Nine reinforced concrete deep beams with dimensions of $750 \mathrm{~mm} \times 350 \mathrm{~mm} \times 75 \mathrm{~mm}$ were tested to destruction by applying gradually increased load. The theoretical formula obtained by Kong and Sharp's was modified to calculate the ultimate load which compared by experimental results. The results gives clear indicator that the behavior and strength of deep beam affected by the location of openings and the amount of web reinforcement, either in the form of discrete fibers or as continuous reinforcement. The effects of opening sizes and locations on the shear strength behavior of reinforced concrete deep beams without web reinforcement were studied by Amin et al. (2013). Many parameters effect the behavior of beam such as $\left(\frac{l}{d}, \frac{a_{\mathrm{v}}}{d}, f_{\mathrm{c}}\right.$ and maximum size of aggregate) was taken into account. The finite element method with (ANSYS + CIVILFEM) release 12.0 program was used to predict the main parameters. From the results they were reported that the main parameters were effected the behavior of deep beam.

Sharp (1977) concerned with the general behavior in shear of single-span reinforced concrete deep beams and in particular the effects of web openings on their ultimate strength and serviceability. The test specimens comprised 75 lightweight and sixteen normal weight reinforced concrete deep beams with span-to-depth ratios ranging from one to two. The effects of a varied range of web openings on deflections, crack widths, cracking loads, failure modes, and ultimate shear strengths were studied, and the influence of web reinforcement was investigated.

\section{Opening beams with strengthening}

El Maaddawy and Sherif (2009) investigated thirteen deep beams with openings under four-point bending to examine the potential use of externally bonded CFRP composite sheets as a strengthening solution to upgrade this kind of beams. All beams has same rectangular section of $80 \times 500 \mathrm{~mm}$ and $1200 \mathrm{~mm}$ length, Test parameters included the opening size, location, and the presence of the CFRP sheets. Externally bonded CFRP shear strengthening around the openings was found very effective in upgrading the shear strength of RC deep beams. The strength gain caused by the CFRP sheets was in the range of 35-73\%. Results predicted from theoretical methods compared with experimental results were within a $15 \%$ error band and varied between 0.92 and 1.34 for un-strengthened and strengthened specimens, respectively. The behavior of RCC beam with rectangular opening strengthened by CFRP and GFRP sheets were studied by Diggikar et al. (2013). Beams were strengthened externally by CFRP and GFRP sheets with different strengthening techniques, i.e., around the opening, inside the opening, inside and around the opening and double layer around the opening. From their experimental results it is concluded that the ultimate load carrying capacity of the RCC beam with opening strengthened with GFRP sheets of different schemes were increased in the range of 3.74-37.41\% and beams strengthened with CFRP sheets increased in the range of 9.35-50.50\%. Ali et al. (2011) investigated the effect of the shape and dimensions of opening on the behavior of RC beams and they was examined the effectiveness of CFRP reinforcement in enhancing the flexural capacity of RC beams with opening at the flexural region. Results obtained from the study show that the $\left(\frac{L}{h}\right)$ ratio and FRP sheets has great effect to increase the stiffness and capacity of all beams.

Strengthening RC beams with large circular and square opening located at flexure zone by CFRP laminates was studied in Chin et al. (2011). They were explained clearly from the test results that large opening at flexure reduces the beam capacity and stiffness; and increases cracking and deflection. Test results showed that large opening at flexure reduces the beam capacity and stiffness; and increases cracking and deflection. An extensive experimental program consisting of testing 11 full scale RC beams were carried out by Vuggumudi (2013). The variables investigated in this study included steel stirrups, shear span-todepth ratio, GFRP amount. The test results illustrated in the present study showed that the external strengthening with GFRP composites can be used to increase the shear capacity of RC T-beams, but the efficiency varies depending on the test variables such as fiber orientations, wrapping schemes, number of layers and anchorage scheme. The shear capacity of these beams has increased compared to the control beam which can be further improved if the debonding failure is prevented.

\section{Analytical studies on performance RC beams with openings}

A finite element FEM reinforced concrete model by using ANSYS 9 finite element program for both un-strengthened and CFRP-strengthened beams with opening using 
concrete element model $25 \times 25 \times 25 \mathrm{~mm}$ and discrete and smeared steel elements models was analyzed (Mahmoud 2012). The obtained deflection results have been compared with other experimental and FE model results in which using concrete element $100 \times 42.5 \times 42.5 \mathrm{~mm}$, smeared steel distribution, and modeling CFRP with ANSYS 5 program and the results of studied parameters such as the maximum strains values for concrete and steel at failure loads for different opening sizes are very close. The prediction equations of torsional strength and failure mode of reinforced concrete beams with or without a small transverse opening based on the skew bending model were developed by Hasnat and Akhtanizzamam (1987). The ratio between top and bottom longitudinal reinforcement, the torsion-moment ratio, and the moment-shear ratio are main parameters. The theoretical results presented gave quite close agreement with the experimental results. Al-Shaarbaf et al. (2007) developed a three-dimensional nonlinear finite element model suitable for the analysis of reinforced concrete beams with large openings under flexure. Numerical studies including some material parameters such as concrete compressive strength, amount of longitudinal tensile reinforcement and opening size on the load-deflection response were conducted. The finite element results showed that the extent of the bottom steel reinforcement decreased with an increase in the length or depth of the opening and the ultimate load and post-cracking stiffness increased with an increase in the concrete compressive strength.

Hawileh et al. (2012) developed 3D nonlinear finite element (FE) models for twelve reinforced concrete deep beams containing web openings and strengthened in shear with CFRP composite sheets. They used the FE models, solid elements for concrete, multi-layer shell elements for CFRP and link elements for steel reinforcement to simulate the physical models. The developed FE models can serve as a numerical platform for performance prediction of $\mathrm{RC}$ deep beams with openings strengthened in shear with CFRP composites. Experimental data published in the literature compared with the FE results to demonstrate the validity of the computational models in capturing the structural response for both un-strengthened and CFRPstrengthened deep beams with openings. The predicted failure loads and deflection capacities were within 3.2 and $14 \%$ error band, respectively. Two cases of simply supported reinforced concrete rectangular section beams with circular and square opening were investigated numerically. The results obtained from finite element analysis software (ANSYS 10) showed that the performance of the beams with circular openings with diameter less than 0.48 of the beam depth has no effect on the ultimate load capacity of the $\mathrm{RC}$ rectangular section beams. The ultimate shear capacity of the beams reduced by $26 \%$ when the opening exceeding 0.48D (Amiri and Masoudnia 2011).

Ultimate strength analysis method of steel-concrete composite beams with unreinforced rectangular web openings is presented. Complete interaction between the steel beam and concrete slab is assumed in the analysis. Comparisons are made with test results reported in the literature by other investigators and showed good agreement. They also presented the effect of the opening eccentricity, opening height and length on the strength of the composite beam. Fahmy and Hassanein (2002) used finite difference method and developed analytical model to investigate the behavior of composite beams with web openings. Variation of the shear force along the opening length is considered, the results conducted by analytical model were compared with some available experimental results and showed good agreement.

An analytical study on reinforced concrete T-beams strengthened in shear with L-shaped FRP plates was presented to develop design equations for RC beams retrofitted in shear using L-shaped FRP plates (Mofidi et al. 2013). Many type of mode of failure such as FRP overlap failure at the beam soffit, breakout of concrete at the embedded part of the FRP plate and FRP pull-off at the epoxy/FRP interface were presented. To calculate the FRP contribution to the shear resistance of RC beams strengthened with L-shaped FRP plates and distinguish the mode of failure, a new design equation depend on experimental data collected from the literature was developed.

Mohamed et al. (2014) used finite element method to predict the behavior of reinforced concrete deep beams with web openings. The effect of the reinforcement distribution on the beam overall capacity was studied and results compared to the Egyptian code guidelines and shown good agreement. They concluded that the reduction in beam's capacity ranged from 6 to $8 \%$ depending on the opening dimensions, the depth of the opening should not exceed $20 \%$ of the beam overall depth $(0.2 d)$ and the reinforcement distribution should be in the range of $0.1-0.2 H$ for simply supported deep beams. State of the art work on the behavior, analysis and design of RC beams with transverse web openings presented to discuss the structural behavior, classification of openings and guidelines for opening location of RC beams with web openings by various design approaches such as the American Concrete Institute (ACI) approaches, the Architectural Institute of Japan (AIJ) approach and the strut and tie method (Ahmed et al. 2012; Osman et al. 2016). Finite element investigation of steel beams with large web openings of various shapes and sizes was carried out to study the failure modes, moment-shear interaction and yield patterns (Chung et al. 2003; Liu and Chung 2003). Results showed that all steel beams with large web openings of various 
shapes behave similarly under a wide range of applied moments and shear forces. An extensive parametric study using finite element method, a simple empirical design method applicable for perforated sections with web openings of various shapes and sizes is developed.

Nonlinear finite element modeling and analysis of steel fiber reinforced concrete (SFRC) deep beams with and without openings in web subjected to two-point loading was presented by Majeed (2012a, b). The percentage of steel fiber used in the study was varied from 0 to $1.0 \%$. The study concluded that the location of openings and the amount steel fiber are affects to the behavior and strength of deep beams. The results obtained by using finite element analysis are very close to that obtained by experimental work. Majeed (2012a, b) studied the experimental and nonlinear finite element (ANSYS 11) analysis to creating square openings in existing RC beams and strengthening with CFRP laminate. The results indicated that the strengthened beam recorded the highest failure load and its mode of failure was ductile. Chin et al. (2012) presented two dimensional nonlinear finite element analyses of RC beams to validate against the laboratory test results. The results of the finite element model show good agreement with that of the experimental beams. Mansur (2006) summarized the analysis and designs of such beams under the most commonly encountered loading case of bending and shear. It has been shown that the design method for beams with large openings can be further simplified without sacrificing rationality and having unreasonable additional cost, and he was explained how to creating an opening in an already constructed beam and how to deal with multiple openings.

The design specifications of openings in the web for simply supported reinforced concrete beams and rectangular concrete beams conducted by previous researchers were reviewed. Investigation of the strength losses in RC beam due to the presence of large square openings placed at two different locations in shear region was examined by Amiri et al. (2011). Also, in order to re-gain the beam structural capacity loss due to the openings, strengthening by CFRP laminates around the openings were studied. Nonlinear finite element program ATENA was used to validate the results. The mid-span deflection and cracks patterns of tested beams obtained by finite element model showed good agreement with the experimental data. The effects of opening shape and location on the structural strength of RC deep beams with opening was studied (Alsaeq 2013). The numerical results show fair agreement with the experimental results with a difference of no more than $20 \%$. The present work concludes that the opening location has more effect on the structural strength than the opening shape. It was concluded that placing the openings near the upper corners of the deep beam may double the strength, and the use of a rectangular narrow opening, with the long sides in the horizontal save up to $40 \%$ of structural strength of the deep beam. Saksena and Patel (2013) used finite element method using ANSYS 14.0 to simulate the simply supported concrete beams consisting of circular openings with varying diameters at different locations. Numerous models of simply supported reinforced concrete rectangular section beams with circular opening were loaded monotonically with two incremental concentrated loads. The beams were simulated to obtain the load-deflection behavior and compared with the solid concrete beam. The results obtained from this study showed that the performance of the beams with circular openings at center of span has lesser effect on the ultimate load capacity of the $\mathrm{RC}$ rectangular section beams. Introducing the circular opening of diameter of $45 \%$ of depth near the support reduces the ultimate load capacity of the RC rectangular section beams at least $32 \%$ compared to solid beam.

The compile state of the art information on the behavior, analysis, and design concrete beams that contain transverse openings through the web was conducted by Mansur and Tan (1999). The behavior of such beams under bending, shear, and torsion is treated in the book. Design methods based on plastic hinge mechanism, plasticity truss and strut-and-tie models, and skew-bending theory are described and illustrated with numerical example. A set of simple and reliable design equations for high strength concrete deep beams with opening was developed by Yoo (2011). Deep beams with web opening but without web reinforcement are given particular attention in his investigation. The finite element method was used to conduct a series of parametric studies and the failure mechanism of concrete deep beams with opening was offered by numerical analysis through detailed examination of their ultimate load versus crack patterns and deflection response. Several researchers presented an analytical discussion of current research and findings on reinforced concrete beams with openings at home and abroad covering its classification, mechanical property, modes of collapse, calculation of shear strength, deflection and crack characteristics (Yao 2005; Hong-jian and Feng-chao 2009). Finite element analysis method is introduced and results compared with that obtained from the seismic performance analysis. Seismic behaviors of steel moment resisting frame including opening in beam web was investigated ( $\mathrm{Li}$ et al. 2006; Jiang et al. 2008; Hui-rong 2009). Experimental results show that steel moment resisting frame (MRF) including opening in beam web closed to connection can satisfy the design requirement. Results shown that, rotations around beam-to-column connection decrease and brittle weld fracture can be avoided and seismic behaviors of steel MRF are improved due to opening in beam web. Analysis results show that with appearance of opening in 
beam web, the rigid of steel MRF is not weakened, and the failure mode of a ductile frame is formed.

\section{Evaluation of some equations presented in common codes and methods}

The following equations give brief review of the shear design method for RC beams specified in the ACI codes and other common codes of practice.

\section{ACI codes}

\section{Beams without opening}

The ACI code suggested two alternative methods (ACI 1995, 2002, 2005, 2008):

(a) Detailed method: The detailed method makes an attempt to include the effect of concrete strength, dowel action of longitudinal reinforcement bars, and the momentto-shear ratio at the section on ultimate shear strength. The equation predicting the shear strength of a beam is given:

$V_{\mathrm{c}}=\frac{1}{6}\left[\sqrt{f_{\mathrm{c}}^{\prime}}+100 \frac{\rho_{\mathrm{w}} V_{\mathrm{u}} d}{M_{\mathrm{u}}}\right] b_{\mathrm{w}} d \leq 0.3 \sqrt{f_{\mathrm{c}}^{\prime}} b_{\mathrm{w}} d$

which $V_{\mathrm{u}}, M_{\mathrm{u}}$ are factored shear force and factored moment respectively; $\rho_{\mathrm{w}}$ is reinforcement ratio; $b_{\mathrm{w}}$ is web width; and $d$ is effective depth; and $\frac{V_{\mathrm{u}} d}{M_{\mathrm{u}}} \leq 1.0$.

(b) Simplified method: the ACI code permits use of below equation to predict shear strength:

$V_{\mathrm{c}}=\frac{1}{6} \sqrt{f_{\mathrm{c}}^{\prime}} b_{\mathrm{w}} d$.

If values of $\rho_{\mathrm{w}}$ are less than 0.0012 , the following equation is suggested

$V_{\mathrm{c}}=\left(0.07+8.3 \rho_{\mathrm{w}}\right) \sqrt{f_{\mathrm{c}}^{\prime}} b_{\mathrm{w}} d$.

For beams with shear reinforcement, the ACI consider nominal shear strength, $V_{\mathrm{n}}$ as flow:

$V_{\mathrm{n}}=V_{\mathrm{c}}+V_{\mathrm{s}}$

which $V_{\mathrm{c}}$ is shear strength of concrete; $V_{\mathrm{s}}$ is shear strength of shear reinforcement.

Shear strength for inclined stirrup at an angle $\alpha$ with horizontal suggested as:

$V_{\mathrm{s}}=\frac{A_{\mathrm{v}} f_{\mathrm{yv}}(\sin \propto+\cos \propto) d}{s}$

which $A_{\mathrm{v}}, f_{\mathrm{yv}}$ are area of shear reinforcement in distance $\mathrm{s}$ and is the yield strength of shear reinforcement, respectively (Fig. 4).

When $\alpha=90^{\circ}$ (vertical stirrups are used) the above equation reduces to
$V_{\mathrm{s}}=\frac{A_{\mathrm{v}} f_{\mathrm{yv}} d}{s}$

but $\emptyset V_{\mathrm{s}} \geq V_{\mathrm{s}}$.

Minimum shear reinforcement, maximum stirrup spacing and maximum shear were provided from following equations, respectively:

$\left[\frac{A_{\mathrm{v}}}{s}\right]_{\min }=\frac{1 b_{\mathrm{w}}}{3 f_{\mathrm{yv}}}$

$S_{\max } \frac{d}{4} \leq 600 \mathrm{~mm}, \quad$ when $\quad 0.5 \emptyset V_{\mathrm{c}}<V_{\mathrm{u}} \leq 3 \emptyset V_{\mathrm{c}} \quad$ and

$S_{\max }=\frac{d}{4} \leq 300 \mathrm{~mm}$,

when $3 \emptyset V_{\mathrm{c}}<V_{\mathrm{u}} \leq 5 \emptyset V_{\mathrm{c}}$

$\left[V_{\mathrm{u}}\right]_{\max }=5 \emptyset V_{\mathrm{c}}=\frac{5}{6} \emptyset \sqrt{f_{\mathrm{c}}^{\prime}} b_{\mathrm{w}} d$.

Formulations for the shear resistance of external FRP sheets bonded to a rectangular beam are often described differently by various researches and design guidelines. Most are in fact based on the same equation that incorporates beam geometry, FRP geometry, and FRP effective strength or strain. This basic equation for the unfactored shear resistance attributed to FRP can be expressed in the following form (ACI 2008; Aykac et al. 2013):
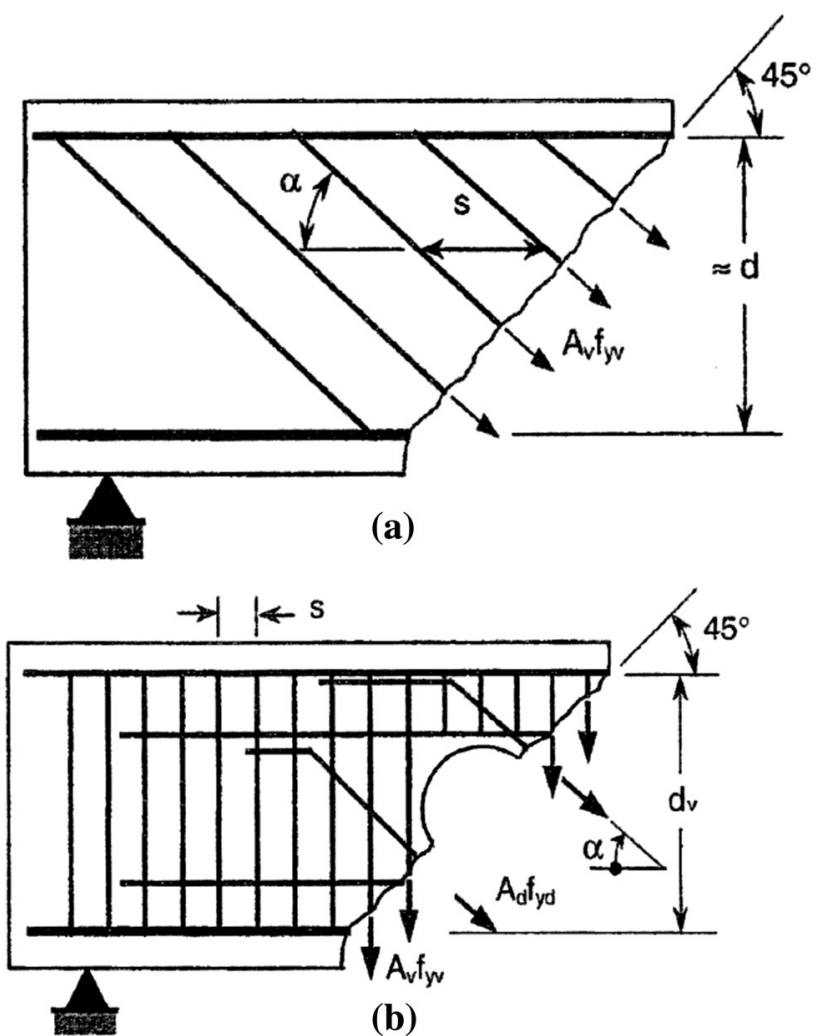

Fig. 4 Shear strength $v_{\mathrm{s}}$ provided by shear reinforcement at a solid beam, b beam with an opening (Mansur and Tan 1999) 
$V_{\mathrm{u}}=f_{\mathrm{fe}} \rho_{\mathrm{uf}} b_{\mathrm{w}} d_{\mathrm{f}}\left(\cot \theta+\cot \beta_{\mathrm{f}}\right) \sin \beta_{\mathrm{f}}$,

where $\rho_{\mathrm{f}}=$ the FRP reinforcement ratio, $b_{\mathrm{w}}=$ the beam web width, $f_{\text {fe }}=$ the FRP effective stress in the principal fiber direction, and $\theta=$ the principal compressive stress inclination. The FRP effective stress is defined as the effective strain multiplied by the modulus of elasticity $E_{\mathrm{f}}$. The term $\beta_{\mathrm{f}}=$ the angle of the FRP principal tensile fibers, measured with respect to the member longitudinal axis. The term $d_{\mathrm{f}}=$ the effective depth of the FRP, the definition and calculation of which varies by code, and is sometimes presented as the effective height, $h_{\text {fe }}$. The FRP reinforcement ratio is defined as follows:

$\rho_{\mathrm{f}}=\left(\frac{A_{\mathrm{f}}}{S_{\mathrm{f}} b_{\mathrm{w}}}\right)=\left(\frac{2 t_{\mathrm{f}} w_{\mathrm{f}}}{S_{\mathrm{f}} b_{\mathrm{w}}}\right)$

$A_{\mathrm{f}}$ is calculated as the total FRP thickness on both beam web faces multiplied by the width of a FRP strip $\left(w_{\mathrm{f}}\right)$.

\section{Beams with opening}

When the beam contains a small opening, the term $\mathrm{d}$ replaced by net depth, $\left(d-d_{0}\right)$, then the nominal shear strength of beam without shear reinforcement, but containing opening becomes

$V_{\mathrm{c}}=\frac{1}{6} \sqrt{f_{\mathrm{c}}^{\prime}} b_{\mathrm{w}}\left(d-d_{0}\right)$.

For beams with shear reinforcement, the ACI consider nominal shear strength, $V_{\mathrm{n}}$ as flow:

$V_{\mathrm{n}}=V_{\mathrm{c}}+V_{\mathrm{s}}$

$V_{\mathrm{s}}=V_{\mathrm{sv}}+V_{\mathrm{sd}}=\frac{A_{\mathrm{v}} f_{\mathrm{yv}}}{s}\left(d_{\mathrm{v}}-d_{0}\right)+A_{\mathrm{d}} f_{\mathrm{yd}} \sin \propto$

$V_{\mathrm{sv}}$ and $V_{\mathrm{sd}}$ is the contribution of vertical and diagonal reinforcement, respectively, $V_{\mathrm{d}}$ is total area of diagonal reinforcement, $\propto$ is reinforcement inclination angle and $f_{\mathrm{yv}}$ is diagonal reinforcement yield strength.

\section{Japanese code (Architectural Institute of Japan (AIJ) 1994)}

The Architectural Institute of Japan (AIJ) code showed the shear strength estimation of reinforced concrete beam with opening through this formula:

$V_{\mathrm{n}}=\left[\frac{0.092 k_{\mathrm{u}} k_{\mathrm{p}}\left(f_{\mathrm{c}}^{\prime}+17.7\right)}{\frac{M}{V \cdot d}+0.12}\left(1-\frac{1.61 d_{0}}{h}\right)+0.846 \sqrt{\rho_{\mathrm{w}}^{-} f_{\mathrm{yv}}}\right] b d_{\mathrm{v}}$.
In this equation $\rho_{\mathrm{w}}$ is ratio of shear reinforcement around the opening, and $k_{\mathrm{u}}$ and $k_{\mathrm{p}}$, are factors which are dependent to the height of section and the ratio of longitudinal reinforcement, respectively.

$\rho_{\mathrm{w}}^{-}=\frac{A_{\mathrm{v}}(\sin \propto+\cos \propto)}{s \cdot d_{\mathrm{v}}}$,

where $d_{\mathrm{v}}$ is the distance between the top and bottom longitudinal bars; $A_{\mathrm{v}}$ is area of web reinforcement (vertical stirrup or diagonal bar); $\alpha$ is angle of inclination of web reinforcement; and $f_{\mathrm{yv}}$ is yield strength of web reinforcement.

The method of plastic truss will obtain the shear strength of segment with opening from the following equations:

$V_{\mathrm{n}}=b d_{\mathrm{tw}} \rho_{\mathrm{v}} f_{\mathrm{yv}} \cos \emptyset_{\mathrm{s}}$

$d_{\mathrm{tw}}=-d_{\mathrm{v}}-\frac{d_{0}}{\cos \emptyset_{\mathrm{s}}}-S_{\mathrm{v}} \tan \emptyset_{\mathrm{s}}$.

The contribution of FRP in shear strength obtained from following equation:

$V_{\mathrm{f}}=K f_{\text {fud }}\left(\frac{A_{\mathrm{f}}}{S_{\mathrm{f}}}\right)\left(\sin \beta_{\mathrm{f}}+\cos \beta_{\mathrm{f}}\right) Z$,

where $z=$ the lever arm length, taken as $d / 1.15$. The term $f_{\text {fud }}$ is the ultimate tensile strength of the FRP in MPa, which is reduced by an efficiency factor given as:

$K=1.68-0.67 R$,

where $K$ was determined through the regression of experimental results and is to be taken between 0.4 and 0.8 . The term $R$, is taken between 0.5 and 2 , and is given by the following:

$R=\left(\rho_{\mathrm{f}} E_{\mathrm{f}}\right)^{1 / 4}\left(\frac{f_{\text {fud }}}{E_{\mathrm{f}}}\right)^{2 / 3}\left(\frac{1}{f_{\mathrm{c}}^{\prime}}\right)^{1 / 3}$.

\section{Plasticity method}

In a beam with openings, however, it is difficult to develop an arch mechanism, and consequently, the applied shear is transferred by means of a truss mechanism. A beam has a circular opening only when the beam is reinforced transversely by vertical stirrups, as shown in Fig. 5 . The effective depth $d_{\mathrm{tw}}$ for the truss mechanism is defined as:

$A_{\mathrm{tw}}=d_{\mathrm{v}}-\frac{d_{0}}{\cos \emptyset_{\mathrm{s}}}-S_{\mathrm{v}} \tan \emptyset_{\mathrm{s}}$,

where $d_{0}$ is the diameter of the circular opening (or that of a circumscribed circle in the case of a square or rectangular opening), and $\mathrm{S}_{\mathrm{v}}$ is the spacing between the two stirrups, one on each side adjacent to the opening. Assuming 
yielding of stirrups, the concrete compressive stress in the shaded portion is given by:

$f_{\mathrm{cw}}=\rho_{\mathrm{v}} f_{\mathrm{yv}}\left(1+\cos ^{2} \emptyset_{\mathrm{s}}\right)$,

where $\rho_{\mathrm{v}}$ is the ratio of shear reinforcement placed adjacent to the opening and $f_{\mathrm{yv}}$ is the yield strength of the stirrups. The shear strength of the beam with an opening is given by:

$V_{\mathrm{n}}=b d_{\mathrm{tw}} \rho_{\mathrm{v}} f_{\mathrm{yv}} \cos \emptyset_{\mathrm{s}}$.

This applies when diagonal steel reinforcement bars are provided and the development length is anchored outside of the stirrups adjacent to the opening. The contribution of the diagonal bars to the shear capacity is given by:

$V_{\mathrm{nd}}=A_{\mathrm{d}} f_{\mathrm{yd}} \sin \theta_{\mathrm{d}}$,

where $\theta_{\mathrm{d}}$ is the angle of inclination to the axis of the beam, and $A_{\mathrm{d}}$ is the cross-sectional area of the diagonal bars, $d_{\mathrm{tw}}$ is the effective depth and $\Phi_{\mathrm{s}}$ is angel of diagonal compression struts of concrete element.

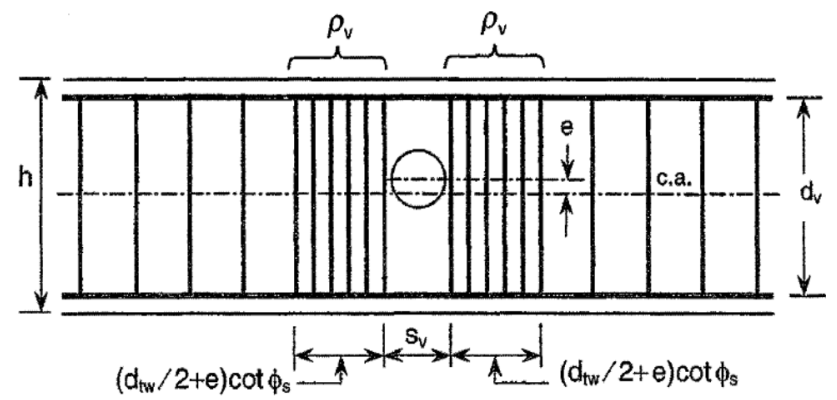

(a) Arrangement of reinforcement (vertical stirrups)

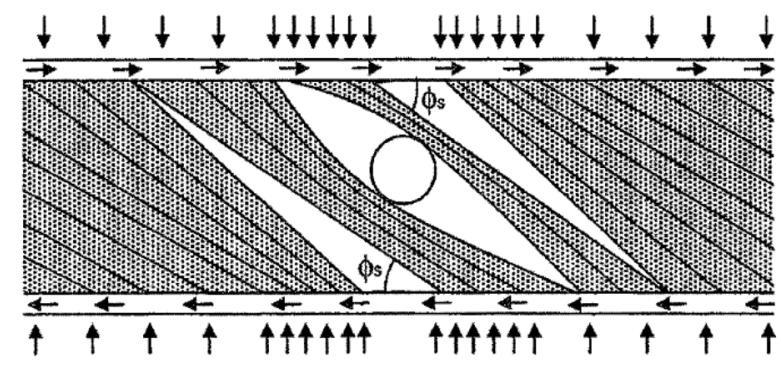

(b) Truss model

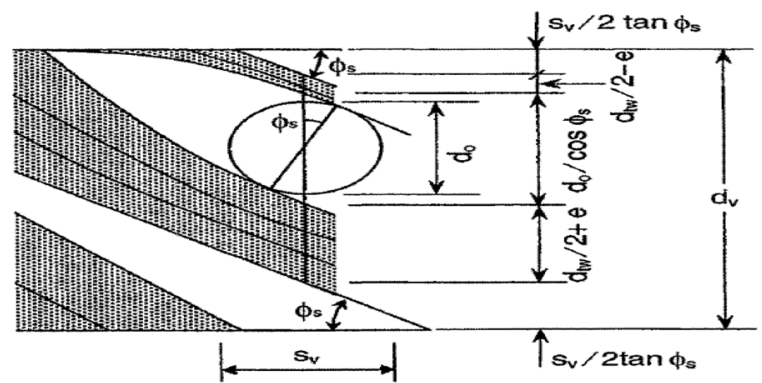

(c) Truss near the opening

Fig. 5 Truss action in beam with opening (Ahmed et al. 2012)

\section{Plastic hinge method}

This method was developed by Mansur and Tan (1999); they stated three steps to set design equation of RC beams with opening.

(1) Determination of longitudinal reinforcement for the compression chord: The top reinforcement will be lighter than the bottom reinforcement when the beam is subject to a sagging moment and the same amount is usually continued throughout the length of the beam, including the opening region. To restore the strength and avoid brittle failure of the beam due to the provision of openings additional reinforcement is required

(2) Determination of the shear force carried by the compression chord: The axial force acting on compression chord, the axial forces $\left(N_{\mathrm{t}}\right.$ and $\left.N_{\mathrm{b}}\right)$, the bending moments $\left(M_{\mathrm{t}}\right.$ and $\left.M_{\mathrm{b}}\right)$, and the shear forces $\left(V_{\mathrm{t}}\right.$ and $\left.V_{\mathrm{b}}\right)$ are given by:

$M_{\mathrm{t}}+M_{\mathrm{b}}+N_{\mathrm{z}}=M_{\mathrm{m}}$

$V_{\mathrm{t}}+V_{\mathrm{b}}=V_{\mathrm{m}}, \quad$ (Torunbalci)

where $M_{\mathrm{m}}$ and $V_{\mathrm{m}}$ are the applied moment and shear force, respectively.

If the contra flexure points occur at the midpoint of the chord members $\left(M_{\mathrm{t}}=M_{\mathrm{b}}=0\right)$, then

$N_{\mathrm{t}}+N_{\mathrm{b}}=0$

$N_{\mathrm{z}}=M_{\mathrm{m}}$.

Shear force which can be transmitted through the compression chord at ultimate may be obtained as:

$(V u)_{\mathrm{t}}=2(M u)_{\mathrm{t}} \times 2 / l_{0}$,

where $l_{0}$ is the length of opening (Fig. 6).

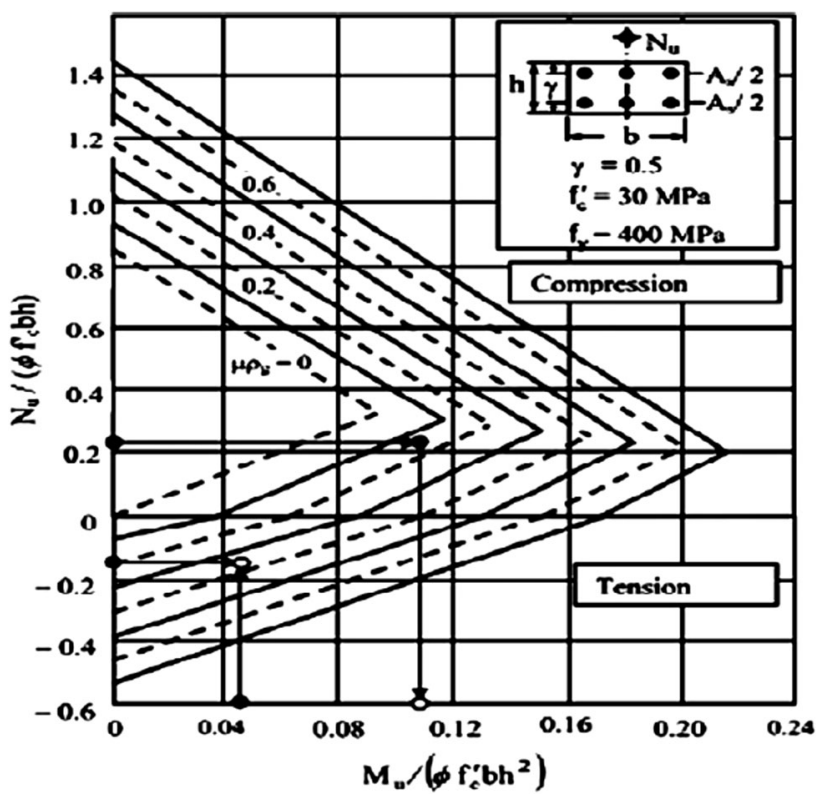

Fig. 6 Typical design chart (Ahmed et al. 2012) 
Table 1 Comparison between experimental and theoretical results from some published papers

\begin{tabular}{|c|c|c|c|c|c|c|c|c|}
\hline References & $\begin{array}{l}\text { Beam } \\
\text { definition }\end{array}$ & $\begin{array}{l}\text { Opening size } \\
(\mathrm{mm})\end{array}$ & $\begin{array}{l}\text { Opening from } \\
\text { support }\end{array}$ & $f_{\mathrm{y}}$ & $f_{\mathrm{yv}}$ & $f_{\text {cu }}$ & $V_{\text {ex. }}$ & $V_{\text {Theo. }}$ \\
\hline \multirow[t]{3}{*}{ Javad and Morteza (2004) } & NDB35-D & 80 (circle) & 350 & 450 & 250 & 30.7 & 57.5 & 59.70 \\
\hline & NDB35-SD & 80 (circle) & 350 & 450 & 250 & 30.1 & 60 & 59.70 \\
\hline & NDB35-S & 80 (circle) & 350 & 450 & 250 & 29.9 & 55 & 51.40 \\
\hline \multirow[t]{2}{*}{ Majeed $(2012 a, b)$} & WBOA & $65 \times 80$ & 182 & 415 & 300 & & 173 & 163.76 \\
\hline & WBOB & $65 \times 80$ & 182 & 415 & 300 & & 165 & 150.23 \\
\hline \multirow[t]{3}{*}{ Alsaeq (2013) } & B1 & $75 \times 75$ & 100 & 517 & 250 & 28.5 & 170 & 159.10 \\
\hline & B2 & $75 \times 75$ & 100 & 517 & 250 & 28.5 & 142.5 & 123.56 \\
\hline & B3 & $75 \times 75$ & 100 & 517 & 250 & 28.5 & 165 & 140.54 \\
\hline \multirow{3}{*}{$\begin{array}{l}\text { Vengatachalapathy and Ilangovan } \\
\text { (2010) }\end{array}$} & WBOA & $80 \times 65$ & 182 & 415 & 300 & 29 & 176.4 & 176.35 \\
\hline & WBOB & $80 \times 65$ & 182 & 415 & 300 & 29 & 168.5 & 168.48 \\
\hline & WWBO & - & - & 415 & 300 & 29 & 208.5 & 211.69 \\
\hline \multirow[t]{10}{*}{ Amin et al. (2013) } & S1-1 & & & 430 & 250 & 28.85 & $3.85^{\mathrm{a}}$ & 3.470 \\
\hline & S1-2 & & & 430 & & 29.36 & $3.5^{\mathrm{a}}$ & 3.180 \\
\hline & S1-3 & & & 430 & & 29.24 & $3.08^{\mathrm{a}}$ & 2.900 \\
\hline & S1-4 & & & 430 & & 26.25 & $2.42^{\mathrm{a}}$ & 2.210 \\
\hline & S1-5 & & & 430 & & 42.3 & $4.70^{\mathrm{a}}$ & 4.420 \\
\hline & S1-6 & & & 430 & & 43.5 & $4.12^{\mathrm{a}}$ & 4.030 \\
\hline & S1-7 & & & 430 & & 32.07 & $3.02^{\mathrm{a}}$ & 2.870 \\
\hline & $\mathrm{S} 1-8$ & & & 430 & & 31.81 & $2.96^{\mathrm{a}}$ & 2.750 \\
\hline & S1-9 & & & 430 & & 32.86 & $3.75^{\mathrm{a}}$ & 3.670 \\
\hline & $\mathrm{S} 1-10$ & & & 430 & & 33.23 & $2.85^{\mathrm{a}}$ & 2.650 \\
\hline \multirow[t]{5}{*}{ Diggikar et al. (2013) } & B1 & $300 \times 100$ & 300 & 450 & 250 & 20 & 79.75 & \\
\hline & $\mathrm{B} 2$ & $300 \times 100$ & 300 & 450 & 250 & 20 & 43.30 & \\
\hline & B3 & $300 \times 100$ & 300 & 450 & 250 & 20 & 54.64 & \\
\hline & B4 & $300 \times 100$ & 300 & 450 & 250 & 20 & 52.21 & \\
\hline & B5 & $300 \times 100$ & 300 & 450 & 250 & 20 & 47.35 & \\
\hline \multirow[t]{15}{*}{ Ali et al. (2011) } & NS1 & - & & 490 & 450 & 25 & 90 & 69.12 \\
\hline & Ns2 & $75 \times 60$ & & 490 & 450 & 25 & 68 & 52.50 \\
\hline & Ns3 & $90 \times 50$ & & 490 & 450 & 25 & 72 & 59.60 \\
\hline & Ns4 & $100 \times 45$ & & 490 & 450 & 25 & 80 & 68.0 \\
\hline & Ns5 & $150 \times 30$ & & 490 & 450 & 25 & 75.35 & 61.3 \\
\hline & Ns6 & $300 \times 15$ & & 490 & 450 & 25 & 75.5 & 58.0 \\
\hline & B1 & - & - & 360 & 250 & 50.3 & 81.7 & 85.6 \\
\hline & B2 & $258 \times 128$ & 562 & 360 & 250 & 49.8 & 70.2 & 61.3 \\
\hline & B3 & $257 \times 130$ & 480 & 360 & 250 & 47.2 & 83.3 & 96.7 \\
\hline & B4 & $260 \times 128$ & 545 & 360 & 250 & 50.5 & 81 & 88.1 \\
\hline & B5 & $264 \times 125$ & 430 & 360 & 250 & 48.5 & 98.3 & 98.9 \\
\hline & B6 & - & 475 & 360 & 250 & 51.5 & 90 & 104.1 \\
\hline & B7 & $320 \times 160$ & - & 360 & 250 & 53.9 & 177.3 & 201.2 \\
\hline & B8 & $320 \times 160$ & 785 & 360 & 250 & 52.3 & 153.7 & 106.5 \\
\hline & B9 & $320 \times 160$ & 735 & 360 & 250 & 49.9 & 170 & 133.9 \\
\hline \multirow[t]{6}{*}{ Tai-yun et al. (2008) } & B10 & $320 \times 160$ & 745 & 360 & 250 & 55.2 & 187.3 & 133.9 \\
\hline & B11 & $320 \times 160$ & 755 & 360 & 250 & 54.1 & 175.9 & 133.9 \\
\hline & B12 & $320 \times 160$ & 789 & 360 & 250 & 52.2 & 183.3 & 133.9 \\
\hline & B13 & $315 \times 160$ & 760 & 360 & 250 & 50.5 & 196.3 & 167.5 \\
\hline & B14 & $320 \times 160$ & 780 & 360 & 250 & 42 & 210.7 & 195.4 \\
\hline & B15 & $320 \times 160$ & 730 & 360 & 250 & 43.1 & 175 & 195.4 \\
\hline
\end{tabular}


Table 1 continued

\begin{tabular}{|c|c|c|c|c|c|c|c|c|}
\hline References & $\begin{array}{l}\text { Beam } \\
\text { definition }\end{array}$ & $\begin{array}{l}\text { Opening size } \\
(\mathrm{mm})\end{array}$ & $\begin{array}{l}\text { Opening from } \\
\text { support }\end{array}$ & $f_{\mathrm{y}}$ & $f_{\mathrm{yv}}$ & $f_{\mathrm{cu}}$ & $V_{\text {ex }}$ & $V_{\text {Theo. }}$ \\
\hline & B16 & $320 \times 160$ & 770 & 360 & 250 & 41.5 & 185.8 & 195.4 \\
\hline & B17 & $320 \times 160$ & 765 & 360 & 250 & 42.2 & 173.3 & 167.3 \\
\hline & B18 & $325 \times 157$ & 640 & 360 & 250 & 40.5 & 192.5 & 195.4 \\
\hline & B19 & $318 \times 165$ & 780 & & & 41.3 & 193.8 & 195.4 \\
\hline & B20 & $318 \times 160$ & 890 & & & 41.3 & 193.8 & 195.4 \\
\hline \multirow[t]{4}{*}{ Mahmoud 2012} & B1 & $100 \times 100$ & 300 & 520 & 350 & 38 & 41 & 41.5 \\
\hline & B2 & $200 \times 100$ & 350 & 520 & 350 & 38 & 43 & 38 \\
\hline & B3 & $300 \times 100$ & 400 & 520 & 350 & 38 & 41 & 34 \\
\hline & B4 & $300 \times 150$ & 400 & 520 & 350 & 38 & 22 & 20 \\
\hline \multirow[t]{14}{*}{ El Maaddawy and Sherif (2009) } & NS-150-C & $150 \times 150$ & 150 & 420 & 300 & 21 & 102.6 & 92.49 \\
\hline & NS-200-C & $200 \times 200$ & 100 & 420 & 300 & 21 & 81.5 & 81.55 \\
\hline & NS-250-C & $250 \times 250$ & 50 & 420 & 300 & 21 & 53.3 & 71.90 \\
\hline & FS-200-C & $200 \times 200$ & 100 & 420 & 300 & 21 & 135.3 & 101.28 \\
\hline & FS-250-C & $250 \times 250$ & 50 & 420 & 300 & 21 & 91 & 98.70 \\
\hline & NS-150-T & $150 \times 150$ & 150 & 420 & 300 & 21 & 130.1 & 125.72 \\
\hline & NS-200-T & $200 \times 200$ & 100 & 420 & 300 & 21 & 110 & 105.66 \\
\hline & NS-250-T & $250 \times 250$ & 50 & 420 & 300 & 21 & 63.8 & 88.25 \\
\hline & FS-250-T & $250 \times 250$ & 50 & 420 & 300 & 21 & 109.7 & 107.82 \\
\hline & NS-150-B & $150 \times 150$ & 150 & 420 & 300 & 21 & 145.7 & 105.19 \\
\hline & NS-200-B & $200 \times 200$ & 100 & 420 & 300 & 21 & 105.3 & 91.97 \\
\hline & NS-250-B & $250 \times 250$ & 50 & 420 & 300 & 21 & 68.95 & 80.10 \\
\hline & FS-250-B & $250 \times 250$ & 50 & 420 & 300 & 21 & 93.3 & 82.50 \\
\hline & $\mathrm{RO} 2$ & $100 \times 100$ & 200 & 400 & 240 & 40 & 43.03 & 38.30 \\
\hline \multirow[t]{4}{*}{ Abdalla et al. 2003} & RO3 & $200 \times 100$ & 200 & 400 & 240 & 40 & 31 & 37.90 \\
\hline & RO4 & $300 \times 100$ & 200 & 400 & 240 & 40 & 17.5 & 38.20 \\
\hline & RO5 & $300 \times 150$ & 200 & 400 & 240 & 40 & 17 & 25.30 \\
\hline & RO6 & $300 \times 150$ & 200 & 400 & 240 & 40 & 17 & 25.30 \\
\hline \multirow[t]{4}{*}{ Al-Shaarbaf et al. (2007) } & $\mathrm{R} 2$ & $600 \times 140$ & 700 & 499 & 355 & 30.4 & 182.5 & 169.8 \\
\hline & R3 & $800 \times 180$ & 600 & 499 & 355 & 33.5 & 144.1 & 143.3 \\
\hline & R6 & $800 \times 180$ & 600 & 499 & 355 & 29.8 & 180 & 160.4 \\
\hline & $\mathrm{R} 11$ & $800 \times 180$ & 600 & 499 & 355 & 28.8 & 133.5 & 132.7 \\
\hline
\end{tabular}

${ }^{a}$ Shear stress in Mpa

(3) Determination of the moments and forces at critical sections and design the tension chord: For symmetry reinforcement, the contra flexure point will be at mid-span and the moment at the critical end section is then given by:

$(M u)_{\mathrm{b}}=(V u)_{\mathrm{b}} / \frac{l_{0}}{2}$.

For symmetrical arrangement of reinforcement, approximated by straight lines, is shown in design chart below when using the capacity reduction factor. A comparison between experimental and theoretical results from some published papers is shown in Table 1.

$\rho g=2 A_{\mathrm{s}} / b h$

$\varphi=0.9, \quad \mu=f_{\mathrm{y}} / 0.85 f_{\mathrm{c}}^{\prime}$.

\section{Conclusions}

The importance of the study in the strengthening of the RC beam with opening using CFRP laminate in the strengthening system provides an economical and multiple solutions for extending the service life of opened reinforced concrete beams. This paper reviewed the existing research works on reinforced concrete beams with transverse web openings strengthened by CFRP, GFRP, steel reinforcement or steel plate and settled the baseline for future researches. The results of this works conclude the following.

The contribution of strengthening materials such as FRP and steel plate in reinforced concrete beams with openings assist engineers to evaluate safety depending on required 
design life, environmental and stress conditions and FRP type. In this work we realized that the theoretical analysis gives more accurate results for RC beams with opening ranged between 0.95 and $1.05 \%$ in case of majority of experimental results that obtained in the previous studies (Table 1). The RC rectangular and T-Beam sections with openings which are strengthened in shear with CFRP laminate, steel plate and combined steel plate joint with CFRP sheets under seismic loading has not been thoroughly investigated. The proposed study is to improve the understanding of reinforced concrete beams with web openings under seismic, dynamic or cyclic load when strengthened with FRP or steel plate to study parameters such as end of anchorage, failure mechanism, FRP orientation, number of FRP layer, spacing, strength scheme, and shear capacity. This proposal gives new challenges for engineering practice, professionals and who are working in the field of strengthening of reinforced concrete structures especially in RC beams with openings.

\section{Recommendations}

Build on the strength of the previous study and considering their limitations we recommend the following techniques to strengthened RC beams with openings:

The use of different options of strengthening techniques, such as bolted steel plate, combined steel plate with FRP, end Anchor, spacing and fiber layer and orientation, to study the real response of strengthened beams with openings to these techniques. Moreover, the parameters including the failure mode, opening size and location, end of anchorage, FRP orientation, number of FRP layer, spacing, strength scheme and shear capacity should be investigated under cyclic, seismic and dynamic load.

The effects of some parameters such as combined shear and torsion, long-term and short-term deflection, effect of thermal expansion and punching shear on shear behavior of strengthened RC beams with openings require more research to improve the practicality of design formulas.

The modification and updating of ACI, AIJ equations and others which obtained by different methods to solve $\mathrm{RC}$ beams with large opening depending on eldest equations and to improve the understanding of reinforced concrete beams with openings strengthened by CFRP or steel plate that subjected to different loading type.

Future researches need more studies in RC beams with opening strengthening by FRP and significant concentration on determination of the suitable number of layers and thickness of FRP at different loading stages as well as finding a relation between several parameters such as shear span, effective span, loading type, beam dimensions and strengthening types. Furthermore, a complete awareness for reinforced concrete beams with opening strengthened with FRP and steel plate under static or dynamic load, owing to efficiently contribution in the concrete structures repair tasks as well as, the reduction of the structure dimensional stability is needed.

More studies are needed on low strength concrete members strengthened by FRP, to examine the efficiency of strengthening on these structures comparing with normal and high strength concrete.

Open Access This article is distributed under the terms of the Creative Commons Attribution 4.0 International License (http://crea tivecommons.org/licenses/by/4.0/), which permits unrestricted use, distribution, and reproduction in any medium, provided you give appropriate credit to the original author(s) and the source, provide a link to the Creative Commons license, and indicate if changes were made.

\section{References}

Abdalla H, Torkey A, Haggag H, Abu-Amira A (2003) Design against cracking at openings in reinforced concrete beams strengthened with composite sheets. Compos Struct 60(2):197-204

ACI (1995) Building code requirements for structural concrete (ACI 318-95) and commentary (ACI 318R-95). American Concrete Institute, Michigan

ACI (2002) Building code requirements for structural concrete (ACI 318-02) and commentary (ACI 318R-02). American Concrete Institute, Michigan

ACI (2005) Building code requirements for structural concrete (ACI 318-05) and commentary (ACI 318R-05). American Concrete Institute, Michigan

ACI (2008) Building code requirements for structural concrete (ACI 318-08) and commentary (ACI 318R-08). American Concrete Institute, Michigan

Ahmed A, Fayyadh M, Naganathan S, Nasharuddin K (2012) Reinforced concrete beams with web openings: a state of the art review. Mater Des 40:90-102

Alferjani M, Samad AA, Elrawaff BS, Mohamad N, Hilton M, Saiah AAS (2013) Use of carbon fiber reinforced polymer laminate for strengthening reinforced concrete beams in shear: a review. Int Refereed J Eng Sci (IRJES) 2(2):45-53

Alferjani MBS, Samad BSEAABA, Mohamad NB, Ahmad MHB (2014) Shear strengthening of reinforced concrete beams using carbon fiber reinforced polymer laminate: a review. Am J Civ Eng 2(1):7

Ali AY, Ibrahim AA, Yousif RF (2011) Analysis of reinforced concrete beams with openings and strengthened by (CFRP) laminates. Univ Babylon Mag 19(3):1098-1113

Alsaeq HM (2013) Effects of opening shape and location on the structural strength of RC deep beams with openings. In: Proceedings of World Academy of Science, Engineering and Technology. World Academy of Science, Engineering and Technology (WASET)

Al-Shaarbaf I, Al-Bayati N, Al-Kaisy D (2007) Nonlinear finite element analysis of reinforced concrete beams with large opening under flexure. Eng Technol 25(2):210-228

Amin HM, Agarwal V, Aziz OQ (2013) Effect of Opening size and location on the shear strength behavior of RC deep beams without web reinforcement. Int $\mathbf{J}$ Innov Technol Explor Eng (IJITEE) 3(7):28-38 
Amiri S, Masoudnia R (2011) Investigation of the opening effects on the behaviour of concrete beams without additional reinforcement in opening region using Fem method. Aust J Basic Appl Sci 5(5):617-627

Amiri S, Masoudnia R, Ameri MA (2011) A review of design specifications of opening in the web for simply supported RC beams. J Civ Eng Constr Technol 2(4):82-89

Architectural Institute of Japan (AIJ) (1994) Structural design guidelines for reinforced concrete buildings, Japan, p 113-118

Ashour AF, Rishi G (2000) Tests of reinforced concrete continuous deep beams with web openings. Struct J 97(3):418-426

Aykac B, Kalkan I, Aykac S, Egriboz YE (2013) Flexural behavior of $\mathrm{RC}$ beams with regular square or circular web openings. Eng Struct 56:2165-2174

Aykac B, Aykac S, Kalkan I, Dundar B, Can H (2014) Flexural behavior and strength of reinforced concrete beams with multiple transverse openings. ACI Struct J 111(2):267

Campione G, Minafò G (2012) Behaviour of concrete deep beams with openings and low shear span-to-depth ratio. Eng Struct 41:294-306

Chen CC, Li CY, Kuo MC (2008) Experimental study of steel reinforced concrete beams with web openings. In: The 14th world conference on earthquake engineering, Beijing, china

Chin S, Shafiq N, Nuruddin M (2011) Strengthening of RC beams containing large opening at flexure with CFRP Laminates. World Acad Sci Technol 60:12-25

Chin S, Shafiq N, Nuruddin M (2012) Strengthening of RC beams with large openings in shear by CFRP laminates: 2D nonlinear FE analysis. World Acad Sci Eng Technol 62:549-554

Chung K, Liu C, Ko A (2003) Steel beams with large web openings of various shapes and sizes: an empirical design method using a generalised moment-shear interaction curve. J Constr Steel Res 59(9):1177-1200

Darwin D, Donahey RC (1988) LRFD for composite beams with unreinforced web openings. J Struct Eng 114(3):535-552

Darwin D, Lucas WK (1990) LRFD for steel and composite beams with web openings. J Struct Eng 116(6):1579-1593

Diggikar R, Mangalgi S, Harsoor R (2013) Behavior of RCC Beam with Rectangular opening Strengthened by CFRP and GFRP sheets. In: International conference on recent innovations in civil engineering

El Maaddawy T, Sherif S (2009) FRP composites for shear strengthening of reinforced concrete deep beams with openings. Compos Struct 89(1):60-69

Fahmy E (1996) Analysis of composite beams with rectangular web openings. J Constr Steel Res 37(1):47-62

Fahmy EH, Hassanein AA (2002) Analysis of composite beams with web opening. In: 4th structural specialty conference of the Canadian Society for Civil Engineering, Canada

Hasnat A, Akhtanizzamam AA (1987) Beams with small rectangular opening under torsion, bending, and shear. J Struct Eng 113(10):2253-2270

Hawileh RA, El-Maaddawy TA, Naser MZ (2012) Nonlinear finite element modeling of concrete deep beams with openings strengthened with externally-bonded composites. Mater Des 42:378-387

Hong-jian C, Feng-chao W (2009) Research development on reinforced concrete beams with openings. J Sanming Univ 26(2):208-212

Hui-rong C (2009) Finite element analysis on hole radius of circular web opening steel beams. J Qingdao Technol Univ 30(3):75-79

Javad V, Morteza H (2004) Effect of small circular opening on the shear and flexural behavior and ultimate strength of reinforced concrete beams using normal and high strength concrete. In: Proceedings of the 13th world conference on earthquake engineering, Vancouver, Canada (paper)
Jiang H, Wei Q, Jiao T, Yan B (2008) Seismic behavior analysis of steel moment frames with opening on beam web [J]. J Henan Polytech Univ (Nat Sci) 3:020

Kim G, Sim J, Oh H (2008) Shear strength of strengthened RC beams with FRPs in shear. Constr Build Mater 22(6):1261-1270

Kong F, Sharp G (1977) Structural idealization for deep beams with web openings. Mag Concr Res 29(99):81-91

Kong FK, Sharp G, Appleton S, Beaumont C, Kubik L (1978) Structural idealization for deep beams with web openings: further evidence. Mag Concr Res 30(103):89-95

Li B, Yang Q, Ru J, Yang N (2006) Investigation on aseismic behaviors of steel moment resisting frame including opening in beam web. Eng Mech 6(23):66-67

Liu T, Chung K (2003) Steel beams with large web openings of various shapes and sizes: finite element investigation. J Constr Steel Res 59(9):1159-1176

Mahmoud AM (2012) Strengthening of concrete beams having shear zone openings using orthotropic CFRP modeling. Ain Shams Eng J 3(3):177-190

Majeed HQ (2012a) Experimental and numerical study of the effects of creating openings in existing $\mathrm{RC}$ beams and strengthening with CFRP. Eng Technol J 30(15):2550-2561

Majeed HQ (2012b) Nonlinear finite element analysis of steel fiber reinforced concrete deep beams with and without opening. J Eng Baghdad Univ 18(12):1421-1438

Mansur M (1998) Effect of openings on the behaviour and strength of $\mathrm{R} / \mathrm{C}$ beams in shear. Cement Concr Compos 20(6):477-486

Mansur M (2006) Design of reinforced concrete beams with web openings. In: Proceedings of the 6th Asia-Pacific structural engineering and construction conference (ASPEC 2006), Citeseer

Mansur M, Alwis W (1984) Reinforced fibre concrete deep beams with web openings. Int $\mathrm{J}$ Cem Compos Lightweight Concr 6(4):263-271

Mansur M, Tan K-H (1999) Concrete beams with openings: analysis and design. CRC Press, Boca Raton

Mansur MA, Tan KH, Lee S-L (1984) Collapse loads of r/c beams with large openings. J Struct Eng 110(11):2602-2618

Mansur M, Lee Y, Tan K, Lee S (1991) Tests on RC continuous beams with openings. J Struct Eng 117(6):1593-1606

Mofidi A, Chaallal O, Shao Y (2013) Analytical design model for reinforced-concrete beams strengthened in shear using L-shaped CFRP plates. J Compos Constr 18(1):04013024

Mohamed AR, Shoukry MS, Saeed JM (2014) Prediction of the behavior of reinforced concrete deep beams with web openings using the finite element method. Alex Eng J 53(2):329-339

Osman BH, Wu E, Ji B, Abdulhameed SS (2016) Shear behavior of reinforced concrete (RC) beams with circular web openings without additional shear reinforcement. KSCE J Civ Eng. doi:10. 1007/s12205-016-0387-7

Pimanmas A (2010) Strengthening R/C beams with opening by externally installed FRP rods: behavior and analysis. Compos Struct 92(8): 1957-1976

Reinforcing Concrete Structures with Fibre Reinforced Polymers (2007) Design manual, ISIS Canada, intelligent sensing for innovative structures, a Canadian network of centres of excellence, University of Manitoba, Winnipeg, No. 3, Version 2. ISBN 0-9689006-6-6

Saksena NH, Patel PG (2013) Experimental study of reinforced concrete beam with web openings. Int J Adv Eng Res Stud Jaers 2

Sharp GR (1977) Reinforced concrete deep beams with web openings. University of Nottingham, Nottingham

Tai-yun H, Jian C, Jing-fen C (2008) Experimental investigation of reinforced concrete beam with rectangular opening. J South China Univ Technol (Natural Science Edition) 36(10):20-24 
Tan K-H, Mansur M, Wei W (2001) Design of reinforced concrete beams with circular openings. ACI Struct J 98(3):407-415

Torunbalci N (2000) Behaviour and design of small square openings in reinforced concrete beams. Archit Sci Rev 43(4):201-210

Torunbalci N (2002) Behaviour and design of large rectangular openings in reinforced concrete beams. Archit Sci Rev 45(2):91-96

Vengatachalapathy V, Ilangovan R (2010) A study on steel fibre reinforced concrete deep beams with and without openings. Int $\mathrm{J}$ Civ Struct Eng 1(3):509

Vuggumudi S (2013) Experimental study on shear strengthening of RC T-beams with web openings using FRP composites.
Department of Civil Engineering, National Institute of Technology, Rourkela, Odisha, India

Yang K-H, Eun H-C, Chung H-S (2006) The influence of web openings on the structural behavior of reinforced high-strength concrete deep beams. Eng Struct 28(13):1825-1834

Yao W (2005) Behavior of the cracks and collapse in reinforced concrete beams with openings. J Jinling Inst Technol 21(2):53-56

Yoo TM (2011) Strength and behaviour of high strength concrete deep beam with web openings. Griffith University, Nathan 